\title{
Relationship between Posture Changes and Each of Ankle Joint Range of Motion and Dynamic Balance
}

\author{
FATMA GABR, M.Sc.*; KHALED AYAD, Ph.D.*; INAS METWALY, Ph.D.* and \\ MOHAMMED SAFWAT, M.D.** \\ The Department of Physical Therapy for Musculoskeletal Disorders and its Surgeries, Faculty of Physical Therapy* and \\ The Department of Orthopedic Surgery, Faculty of Medicine**, Cairo University, Egypt
}

\begin{abstract}
Background: Various activities of daily living require sitting for prolonged periods of time. These activities include driving a car, working on a computer. This can lead to postural changes such as exaggerated forward head posture. Which can lead to over activation of the ankle plantar flexor to maintain body balance. On the other hand, ankle movement may be restricted as the body is connected through fasciae network were the upper quadrant disturbance may affect lower quadrant.
\end{abstract}

Aim of Study: The current study aimed to determine the relationship between forward head posture and both ankle joint range of motion and dynamic balance in 35 healthy students. Their age ranged from 19 to 22 years.

Material and Methods: Posture was evaluated using Biotonix posture print while Biodex stability system was used to evaluate dynamic postural control. Universal goniometer was used to measure ankle joint range of motion.

Results: Three-Dimensional (3-D) head posture changes affected dynamic balance at level four of the Biodex dynamic balance test (only medio-lateral stability index), while no changes were observed in the dynamic balance at level eight. Three-dimensional head posture changes affected ankle joint range of motion.

Conclusion: Three-dimensional head posture changes affected ankle joint range of motion through the fascial system which connects different body segments with each other. Dynamic balance was also affected as changes of head posture alters center of gravity position.

Key Words: Forward head posture-Balance-Ankle ROM - Posture.

\section{Introduction}

PROPER posture is achieved by maintaining musculoskeletal balance associated with minimal stress or strain on the body [1]. Vision, vestibular, soma-

Correspondence to: Dr. Fatma Gabr, The Department of Physical Therapy for Musculoskeletal Disorders and its Surgeries, Faculty of Physical Therapy, Cairo University, Egypt tosensory, musculoskeletal and proprioceptive systems are important factors for balance [2-4] Poor posture results in malalignment of various body parts causing greater risk of musculoskeletal injury due to increased strain on supporting structures $[\mathbf{1 , 5}]$.

Mechanoreceptors (e.g., muscle spindles) in the cervical region, have a main role in providing proprioceptive information [14]. Cervical joint position sense has a major effect on body balance, postural awareness and gait control [15]. Forward Head Posture (FHP) is a common postural disorder caused by extension in the upper cervical vertebra and flexion in lower cervical vertebra, which leads to excessive facet joints loading and weakness of the deep neck flexors and shortening of cervical extensors [6-10]. FHP causes decreased Range of Motion (ROM) in the neck, in the sagittal plane [11], and thus might influence joint position sense via muscle spindles [12]. This can also imply that proprioception becomes worse as FHP becomes more severe [13].

Studies showed that frequent computer users have decreased ability to control posture and maintain balance even if no symptoms of pain or any other musculoskeletal disorders are present [16] This may be explained by anterior head translation position that leads to anterior displacement of Center of Gravity (COG) causing disturbance in both static and dynamic balance resulting in higher incidence for falling and musculoskeletal injuries $[\mathbf{1 7 , 1 8}]$. Another explanation, is FHP is associated with contraction in the cervical extensors and is transmitted through the myofascial system to the plantar flexors of the ankle that are over activated to counter anterior $\mathrm{COG}$ translation, to maintain balance [19] 
Hence, over activation of ankle planter flexors results in disruption of ankle ROM and dynamic balance. This may result in frequent falling and musculoskeletal disorders. The purpose of the current study is to show if there is a relationship between FHP, ankle ROM and dynamic balance.

\section{Material and Methods}

At Cairo University Faculty of Physical Therapy Biodex Lab and at Misr University posure print lab, in the period from December 2015 to January 2017 (thirty-five collegiates with asymptomatic FHP participated in this study. Their age ranged from 19-22 years. Body mass index ranged from 18.5-24.9. Valid and reliable weight and height scales were used to select subjects. Subjects were excluded if they had any of the following: Visual, auditory or perceptual deficits, structural deformities at any joint of the Lower Limbs (LL) and spine, surgical operations in the lower limb, deep sensory loss, history of epilepsy, previous cervical trauma and history of ankle sprain.

Posture was evaluated using the Biotonix posture print which is computer analysis software of posture in terms of rotations in degrees and translation in millimeters [20] posture print computer code calculates static postures of the head, rib cage, and pelvis as in rotations ( $\mathrm{Rx}, \mathrm{Ry}, \mathrm{Rz})$ in degrees [20] and translations as displacements from a normal upright stance ( $\mathrm{Tx}, \mathrm{Tz})$ in millimeters $(\mathrm{mm})[20,21]$. The current study measured head, rib cage, and pelvic postures as rotations and translations in three-dimensions (3-D) during standing (upright stance) using computerized system, posture Print ${ }^{\circledR}$. In two separate validity studies, the posture Print ${ }^{\circledR}$ system was found to be accurate in measuring head and thoracic cage postures in five degrees of freedom which are lateral translation (Tx), lateral flexion $(\mathrm{Rz})$, axial rotation (Ry), flexionextension $(\mathrm{Rx})$, and anterior-posterior translation (Tz) $[21,23]$

Biodex balance system was used to asses dynamic balance for selected subjects.

All subjects were tested on the stability level four and level eight for three times repetitions. Test duration 20 second for each repetition.

At the end of each test trial, a printout report was obtained including information regarding Overall Stability Index (OASI), Mediolateral Stability Index (MLSI) and Anteroposterior Stability Index (APSI). High value represented that the subject had difficulties maintaining balance. Mean values of three trials were calculated for each subject.

\section{Statistical analysis:}

- Descriptive statistics was conducted to calculate the mean, standard deviation $( \pm S D)$ for all measured variables.

- Pearson product moment correlation coefficient was conducted to determine the correlation between variables.

- The level of significance for all statistical tests was set at $p \leq 0.05$.

- All statistical measures were performed through the Statistical Package for Social Studies (SPSS) Version 19 for windows.

\section{Results}

Thirty-five students with forward head posture, 10 females with reported percentage of $29 \%$ and 25 males with reported percentage of $71 \%$ participated in this study. The mean \pm SD of age, weight, height, and BMI were $19.62 \pm 0.73$ years, $67.71 \pm$ $10.25 \mathrm{~kg}, 169.77 \pm 7.17 \mathrm{~cm}$, and $23.5 \pm 3.22 \mathrm{~kg} / \mathrm{m}^{2}$ respectively. Correlation between $3 \mathrm{D}$ head posture changes, dynamic balance and ankle joint ROM showed moderate positive significant correlation between MLSI and head Tx ( $r=0.33, p=0.05)$. Correlations between left ankle active dorsi flexion ROM and head postural changes showed moderate positive significant correlation with head Ry ( $r=$ $0.48, p=0.003$ ).

Correlations between left ankle active plantar flexion ROM and head postural changes showed moderate negative significant correlation with head $\mathrm{Rx}(r=-0.334, p=0.05)$. Correlations between right ankle active dorsi flexion ROM and postural changes indices showed moderate negative significant correlation with head postural index $(r=-0.39, p=$ $0.01)$.

Correlations between right ankle active plantar flexion ROM and postural changes indices showed moderate positive significant correlation with head postural index $(r=0.4, p=0.01)$ and a moderate positive significant correlation with total postural index $(r=0.37, p=0.02)$.

Correlations between left ankle active planter flexion ROM and postural changes indices showed moderate positive significant correlation with head postural index ( $r=0.37, p=0.02)$ and a moderate positive significant correlation with total postural index $(r=0.36, p=0.03)$. 
Table (1): Correlation between stability indices at level 4 and head postural changes.

\begin{tabular}{llll}
\hline Stability index & \multicolumn{1}{c}{$\begin{array}{c}\text { Head postural } \\
\text { changes }\end{array}$} & $\begin{array}{c}r \text { - } \\
\text { value }\end{array}$ & $\begin{array}{c}p \text { - } \\
\text { value }\end{array}$ \\
\hline - Anteroposterior & Head Rx (degrees) & 0.01 & 0.92 \\
stability index & Head Rz (degrees) & 0.1 & 0.55 \\
& Head Ry (degrees) & -0.2 & 0.23 \\
& Head Tz (mm) & 0.14 & 0.4 \\
& Head Tx (mm) & 0.17 & 0.32 \\
- Mediolateral & Head Rx (degrees) & -0.04 & 0.82 \\
stability index & Head Rz (degrees) & 0.15 & 0.37 \\
& Head Ry (degrees) & -0.09 & 0.57 \\
& Head Tz (mm) & 0.1 & 0.55 \\
& Head Tx (mm) & 0.33 & $0.05 *$ \\
- Overall stability & Head Rx (degrees) & 0.03 & 0.82 \\
index & Head Rz (degrees) & 0.12 & 0.46 \\
& Head Ry (degrees) & -0.14 & 0.41 \\
& Head Tz (mm) & 0.12 & 0.49 \\
& Head Tx (mm) & 0.21 & 0.22 \\
\hline
\end{tabular}

$r$-value: Correlation coefficient value.

$p$-value: Probability value.

$p=0.05$ significant.

Table (2): Correlation between stability indices at level 8 and head postural changes.

\begin{tabular}{llll}
\hline Stability index & $\begin{array}{c}\text { Head postural } \\
\text { changes }\end{array}$ & $\begin{array}{c}r- \\
\text { value }\end{array}$ & $\begin{array}{c}p- \\
\text { value }\end{array}$ \\
\hline - Anteroposterior & Head Rx (degrees) & -0.13 & 0.44 \\
stability index & Head Rz (degrees) & 0.17 & 0.31 \\
& Head Ry (degrees) & 0.03 & 0.85 \\
& Head Tz (mm) & 0.17 & 0.32 \\
& Head Tx (mm) & 0.04 & 0.78 \\
- Mediolateral & Head Rx (degrees) & -0.18 & 0.28 \\
stability index & Head Rz (degrees) & 0.04 & 0.78 \\
& Head Ry (degrees) & -0.18 & 0.29 \\
& Head Tz (mm) & 0.14 & 0.41 \\
- Overall stability & Head Tx (mm) & 0.12 & 0.46 \\
index & Head Rx (degrees) & -0.21 & 0.2 \\
& Head Rz (degrees) & 0.21 & 0.22 \\
& Head Ry (degrees) & 0.002 & 0.99 \\
& Head Tz (mm) & 0.19 & 0.25 \\
& Head Tx (mm) & 0.1 & 0.55 \\
\hline
\end{tabular}

$r$-value: Correlation coefficient value.

$p$-value: Probability value.

$p=0.05$ significant.

Table (3): Correlation between stability indices at level 4 and postural changes indices.

\begin{tabular}{llcl}
\hline Stability index & $\begin{array}{c}\text { Postural changes } \\
\text { indices }\end{array}$ & $\begin{array}{c}r- \\
\text { value }\end{array}$ & $\begin{array}{c}p \text { - } \\
\text { value }\end{array}$ \\
\hline - Anteroposterior & Head postural index & -0.06 & 0.7 \\
stability index & Total postural index & -0.23 & 0.17 \\
- Mediolateral & Head postural index & -0.08 & 0.62 \\
stability index & Total postural index & -0.14 & 0.41 \\
- Overall stability & Head postural index & -0.05 & 0.77 \\
index & Total postural index & -0.15 & 0.36 \\
\hline
\end{tabular}

$r$-value: Correlation coefficient value.

$p$-value: Probability value.

$p=0.05$ significant.
Table (4): Correlation between stability indices at level 8 and postural changes indices.

\begin{tabular}{llll}
\hline Stability index & $\begin{array}{c}\text { Postural changes } \\
\text { indices }\end{array}$ & $\begin{array}{c}r \text { - } \\
\text { value }\end{array}$ & $\begin{array}{c}p \text { - } \\
\text { value }\end{array}$ \\
\hline - Anteroposterior & Head postural index & 0.11 & 0.49 \\
stability index & Total postural index & -0.17 & 0.31 \\
- Mediolateral & Head postural index & 0.1 & 0.54 \\
stability index & Total postural index & -0.07 & 0.68 \\
- Overall stability & Head postural index & 0.12 & 0.47 \\
index & Total postural index & -0.17 & 0.3 \\
\hline
\end{tabular}

$r$-value: Correlation coefficient value.

$p$-value: Probability value.

$p=0.05$ significant.

Table (5): Correlation between ankle active ROM and head postural changes.

\begin{tabular}{llll}
\hline $\begin{array}{l}\text { Ankle active } \\
\text { ROM (degrees) }\end{array}$ & \multicolumn{1}{c}{$\begin{array}{c}\text { Head postural } \\
\text { changes }\end{array}$} & $r$-value & $p$-value \\
\hline - Right ankle & Head Rx (degrees) & 0.29 & 0.08 \\
dorsi flexion & Head Rz (degrees) & -0.13 & 0.45 \\
& Head Ry (degrees) & 0.03 & 0.84 \\
& Head Tz (mm) & -0.32 & 0.06 \\
- Right ankle & Head Tx (mm) & 0.12 & 0.47 \\
plantar flexion & Head Rx (degrees) & -0.3 & 0.07 \\
& Head Rz (degrees) & 0.18 & 0.29 \\
& Head Ry (degrees) & 0.2 & 0.23 \\
- Left ankle dorsi & Head Tz (mm) & 0.17 & 0.31 \\
flexion & Head Tx (mm) & 0.13 & 0.43 \\
& Head Rz (degrees) & 0.05 & 0.77 \\
& Head Ry (degrees) & 0.14 & 0.41 \\
- Left ankle & Head Tz (mm) & -0.05 & $0.003 *$ \\
plantar flexion & Head Tx (mm) & 0.03 & 0.77 \\
& Head Rx (degrees) & -0.334 & $0.05^{*}$ \\
& Head Rz (degrees) & 0.21 & 0.22 \\
& Head Ry (degrees) & 0.33 & 0.053 \\
& Head Tz (mm) & 0.15 & 0.36 \\
\hline$r$-value: Correlation coefficient value. & & \\
$p$-value: Probability value. & Head Tx (mm) & 0.05 & 0.77 \\
$p=0.05$ significant. & & &
\end{tabular}

Table (6): Correlation between ankle active ROM and postural changes indices.

\begin{tabular}{llll}
\hline $\begin{array}{l}\text { Ankle active } \\
\text { ROM (degrees) }\end{array}$ & $\begin{array}{c}\text { Postural changes } \\
\text { indices }\end{array}$ & $r$-value & $p$-value \\
\hline - Right ankle & Head postural index & -0.39 & $0.01^{*}$ \\
dorsi flexion & Total postural index & -0.24 & 0.16 \\
- Right ankle & Head postural index & 0.4 & $0.01^{*}$ \\
plantar flexion & Total postural index & 0.37 & $0.02^{*}$ \\
- Left ankle dorsi & Head postural index & 0.23 & 0.18 \\
flexion & Total postural index & 0.327 & 0.055 \\
- Left ankle & Head postural index & 0.37 & $0.02^{*}$ \\
plantar flexion & Total postural index & 0.36 & $0.03^{*}$ \\
\hline $\begin{array}{l}r \text {-value: Correlation coefficient value. } \\
p \text {-value: Probability value. }\end{array}$ & & \\
$p=0.05$ significant. & & &
\end{tabular}




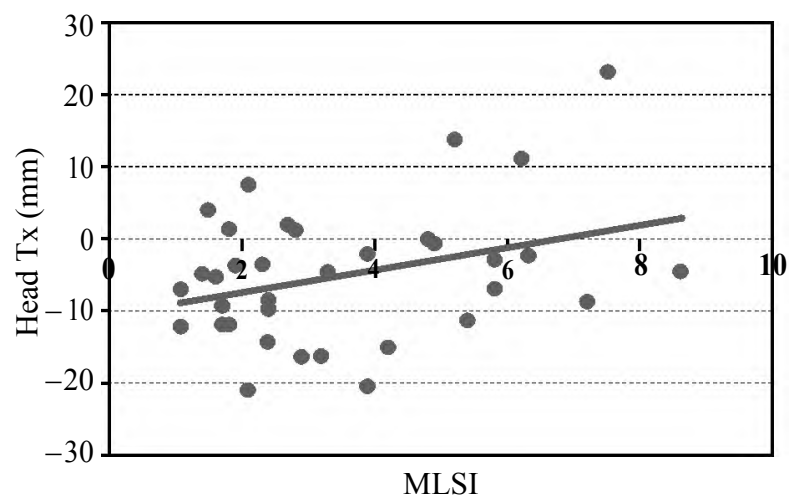

Fig. (1): Correlation between head Tx and MLSI.

\section{Discussion}

Nowadays, use of Visual Display Terminals (VDT) of computers and smart phones is very common [24]. Which results in musculoskeletal disorders such as FHP, which is one of the most common conditions [25]. A study by Kang et al., showed that heavy computer users had significantly decreased ability to control posture and mobility compared to the control group, even though they do not necessarily complain of severe pain caused by musculoskeletal disorders such as myofascial pain syndrome or herniated disc [26] .

Disorders in the cervical region and its connection with balance can be further explained by fascial net which is a continuous net, were when agonist muscles contract the whole myofascial net is affected and pulled into a specific direction, and because of the net's consistency the rest of the muscles are somehow affected [27].

Muscle tension is transmitted by tendons, the endomysium, perimysium and epimysium and by extramuscular connective tissues, such as the deep fasciae and the neurovascular tract [28]. Fasciae play an important role in the transmission of force, thus regulating human posture and balance [29] and in proprioception, as encapsulated receptors (e.g., the Ruffini and Pacini corpuscles) are located within [30] .

According to Myers, the superficial back line is one of myofascial meridians transmitting the tension generated by the head or gastrocnemius to other muscles [31]. The current study confirmed that human muscles relate to each other by fascia enabling interaction with each other, as changes in the head posture affected ankle ROM.

Previous studies observed that increased hamstring muscle flexibility following the release of suboccipital muscles. Through the action of the superficial back line [9], that connects muscles on the posterior side of the body with each other, passive hamstring stretching exercises stretched the cervical extensors, and the stretched extensor loosened the flexors increasing cervical flexion and extension. The passive hamstring stretching exercises also transmitted the force of stretching to muscles related to the pelvis and spine, thereby improving static balance $[\mathbf{1 9 , 3 3 , 3 4 ]}$.

A study by Ellis, [35]. Reported minimal displacement of the sciatic nerve at the thigh during cervical spine flexion in a sitting position.

Peripheral neural tissue is connected to the surrounding fascia through the epineurium, making force transmission not only be through fascial tissue, but also through neural tissue [36] .

During cervical flexion, force transmitted through the fascial pathway may also be transmitted through the posterior lamina of the thoracolumbar fascia, which is one of the main dorsal pathways of force transmission that directly connects to the gluteus maximus and hamstring fascia [37].

The neural pathway, which involves the spinal cord, spinal dura, and lumbosacral roots, creates tension in the sciatic nerve with different types of joint movements, including cervical spine flexion $[38,39]$.

In the hamstring, the fascial tissue and sciatic nerve have a connection through the epineurium. This effect can be explained by a connection of the hamstring tendons with the suboccipital muscle through a neural system that passes through the spinal dura, part of the posterior myofascial chain $[40,41]$.

Cruz-Montecinos et al., [42] in their study to investigate ultrasound assessment of fascial connectivity in the LL during maximal cervical flexion proved displacement of deep fascia thus suggesting myofascial connectivity between the cervical spine and the LL. This agrees with results if the current study where changes in the head posture affected ankle joint ROM.

Hyouk Hyong and Jae Hyun Kim, [43,44] . Examined the effect of forward head posture on ankle joint ROM and static balance reported that forward head posture affects normal ankle plantar flexion ROM through the fascia, which proves that human body parts have transmit tensions arising from different postures among each other through the fascia but no influence on static balance. Tension in the human body is transmitted by fascia through 
myofascial meridians with possible influence on the biomechanics of the distal joints [22]. Which agrees with results of the current study. From a biomechanical point of view, fascia plays important roles in movement restriction and proprioception.

This restriction has been observed in fascial connectivity models, such as between the pelvis and deep fascia of the medial gastrocnemius [43]

And has been reinforced by observations in cadaveric models, which suggest posterior fascial connectivity between the thoracolumbar spine, pelvis, and feet [45]

Sivayogam A, Johnson GM, Skinner MA [46] investigated the influence of change in head posture (e.g., retraction and protrusion) on postural stability. The results demonstrate that in healthy young adult males, no significant difference in the equilibrium score was detected when the head was positioned in protrusion or retraction compared with the neutral head posture in any of the six different test conditions for balance. However, the results from this study suggest that despite protrusion and retraction of the head, postural stability was able to be maintained. The likely explanation is that in protrusion and retraction the head orientation with respect to the horizontal ground surface was unaltered; hence the vestibular system was in a good state to assist with controlling postural stability and furthermore the compression effect on the vertebral artery that can be identified during head extension is not evident in head protrusion and retraction [47].

\section{References}

The results of this study supports our study results as changes of head posture did not affect the dynamic balance.

1- KENDALL F.P., McCREARY E.K. and PROVANCE P.G.: Muscles, Testing and Function: With Posture and Pain. 5th ed. Baltimore, Md: Williams \& Wilkins, 2005.

2- FERREIRA E.A., DUARTE M. and MALDONADO E.P.: Quantitative assessment of postural alignment in young adults based on photographs of anterior, posterior, and lateral views: Manipulative Physiol. Ther., 34: 371-80. [Medline] [Cross-Ref], 2011.

3- KANG J.H., PARK R.Y. and LEE S.J.: The effect of the forward head posture on postural balance in long time computer based worker. Ann. Rehabil. Med., 36: 98-104. [Medline] [Cross Ref], 2012.

4- TRELEAVEN J., JULL G. and LOW CHOY N.: The relationship of cervical joint position error to balance and eye movement disturbances in persistent whiplash: Man. Ther., 11: 99-106. [Medline] [Cross Ref], 2006.

5- GRIEGEL-MORRIS P., LARSON K., MUELLERKLAUS K. and OATIS C.A.: Incidence of common postural abnormalities in the cervical, shoulder, and thoracic regions and their association with pain in two age groups of healthy subjects. Phys. Ther., 72 (6): 425 31, 1992.

6- HARMAN K., HUBLEY-KOZEY C.L. and BUTLER H.: Effectiveness of an exercise program to improve forward head posture in normal adults: A randomized, controlled 10-week trial. J. Manual. Manip. Ther., 13: 163-76. [Cross Ref], 2005.

7- De-La-LLAVE-RINCÓN A.I., FERNÁNDEZ-De-LASPEÑAS C. and PALACIOS-CEÑA D.: Increased forward head posture and restricted cervical range of motion in patients with carpal tunnel syndrome. J. Orthop. Sports Phys. Ther., 39: 658-64. [Medline] [Cross Ref], 2009.

8- YIP C.H., CHIU T.T. and POON A.T.: The relationship between head posture and severity and disability of patients with neck pain. Man. Ther., 13: 148-54. [Medline] [Cross Ref], 2008.

9- SZETO G.P., STRAKER L. and RAINE S.: A field comparison of neck and shoulder postures in symptomatic and asymptomatic office workers. Appl. Ergon., 33: 7584, 2002.

10- YONG M.S., LEE H.Y., RYU Y.U., et al.: Effects of craniocervical flexion exercise on upper-limb postural stability during a goal-directed pointing task. J. Phy. Ther. Sci., 27: 2005-7, 2015

11- CHAE Y.W.: The effect of forward head posture and cervical ROM on chronic and episodic tension-type headache in university students: J. Kor. So. Phys. Ther., 21: 71-7, 2009.

12- MIN-SIK YONG, HAE-YONG LEE and MI-YOUNG LEE: Correlation between head posture andproprioceptive function in the cervical region: J. Phys. Ther. Sci., 28: 857-60, 2016.

13- LEE M.Y., LEE H.Y. and YONG M.S.: Characteristics of cervical position sense in subjects with forward head posture: J. Phys. Ther. Sci., 26: 1741-3, 2014.

14- TRELEAVEN J.: Sensorimotor disturbances in neck disorders affecting postural stability, head and eye movement control. Man. Ther., 13: 2-11. [Medline] [CrossRef], 2008.

15- VUILLERME N., PINSAULT N. and BOUVIER B.: Cervical joint position sense is impaired in older adults. Aging Clinical and Experimental Research, 20: 4, 2007.

16- KANG J.H., PARK R.Y., LEE S.J., et al.: The effect of the forward head posture on postural balance in long time computer based worker. Ann. Rehabil. Med., 36: 98-104, 2012.

17- Di FABIO R.P.: Sensitivity and specificity of platform posturography for identifying patients with vestibular dysfunction. Phys. Ther., 75: 290-305, 1995.

18- LEE C.M., JEONG E.H. and FREIVALDS A.: Biomechanical effects of wearing high-heeled shoes: Int. J. Ind. Ergon., 28: 321-6. [Cross Ref], 2001.

19- In HYOUK HYONG and KANG J.H.: The Immediate Effects of Passive Hamstring Stretching Exercises on the Cervical Spine Range of Motion and Balance J. Phys. Ther. Sci., 25: 113-6, 2013.

20- NORMAND M.C., DESCARREAUX M., HARRISON D.D., HARRISON D.E., PERRON D.L., FERRANTELLI J.R. and JANIK T.J.: Three dimensional evaluation of 
posture in standing with the Posture Print: An intra-and inter-examiner reliability study: Chiropractic \& Osteopathy, 15: 15 doi: 10.1186/1746-1340-15-15, 2007.

21 - HARRISON D.E., JANIK T.J., CAILLIET R., HARRISON D.D., NORMAND M.C., PERRON D.L. and FERRANTELLI J.: Validation of a Computer Analysis to Determine 3-D Rotations and Translations of the Rib Cage inUpright Posture from Three 2-D Digital Images. Eur. Spine J., 16: 213-8, 2007.

22- In HYOUK HYONG, P.T., Ph.D.1 and JAE HYUN KIM, P.T., Ph.D.1: The Effect of Forward Head on Ankle Joint Range of Motion and Static Balance. J. Phys. Ther. Sci., 24: 925-7, 2012.

23- JANIK T.J., HARRISON D.E., CAILLIET R., HARRISON D.D., NORMAND M.C. and PERRON D.L.: Validity of an Algorithm to Estimate 3-D Rotations andTranslations of the Head in Upright Posture from Three 2-D Digital Images. J Manipulative Physiol. Ther., 30: 124-9, 2007.

24- YOO W.G. and KIM M.H. : Effect of Different Seat Support Characteristics on the Neck and Trunk Muscles and Forward Head Posture of Visual Display Terminal Workers. Work, 3 6: 3-8, 2010.

25- YIP C.H., CHIU T.T. and POON A.T.: The Relationship Between Head Posture and Severity and Disability of Patients with Neck Pain. Man. Ther., 13: 148-54, 2008.

26- KANG J.H., PARK R.Y., LEE S.J., et al.: The effect of the forward head posture onpostural balance in long time computer based worker. Ann. Rehabil. Med., 36: 98-104, 2012.

27- MYERS T.W.: Anatomy Trains: Myofascial Meridians for Manual and Movement Therapists. Churchill Livingstone, 2001.

28- HUIJIN, FINDLEY and SCHLEIP R.: Fascia Research II - Basic Science and Implications for Conventional and Complementary Health Care. Elsevier Urban \& Fischer, Munich, 2009.

29- SCHLEIP R., KLINGLER W. and LEHMANN-HORN F.: Active Fascial Contractility: Fascia may be able to Contract in a Smooth Muscle-Like Manner and thereby Influence Musculoskeletal Dynamics: Med. Hypotheses, 65: 273-7, 2005.

30- STECCO C., GAGEY O. and BELLONI A.: Anatomy of the deep fascia of the upper limb. Second part: Study of innervation. Morphologie, 91: 3 8-43, 2007.

31- MYERS T.W.: Anatomy train: Myofascial Meridians for Manual and Movement Therapists (2nd ed). Seoul: Translated by Elsevier Korea LLC, pp. 95-123, 2010.

32- In HYOUK HYONG and JONG HO KANG J.H.: The Immediate Effects of Passive Hamstring Stretching Exercises on the Cervical Spine Range of Motion and Balance: J. Phys. Ther. Sci., 25: 113-6, 2013.

33- CHO S.H., KIM S.H. and PARK D.J.: The Comparison of the Immediate Effects of Application of the Suboccipital Muscle Inhibition and Self-Myofascial Release Techniques in the Suboccipital Region on Short Hamstring: J. Phys. Ther. Sci., 27: 195-7, 2015.

34- APARICIO É.Q., QUIRANTE L.B., BLANCO C.R. and SENDÍN F.A.: Immediate Effects of the Suboccipital
Muscle Inhibition Technique in Subjects with Short Hamstring Syndrome: J. Manipulative Physiol. Ther., 32: 2629,2009 .

35- ELLIS R.F.: Comparison of Different Neural Mobilization Exercises Upon Longitudinal Sciatic Nerve Movement: An In-Vivo Study Utilizing Ultrasound Imaging: J. Orthop. Sports Phys. Ther., 42: 667-75, 2012.

36- HUIJING P.A.: Epimuscular Myofascial Force Transmission: A Historical Review and Implications for New Research: International society of biomechanics Muybridge award lecture, Taipei, 2007. J. Biomech., 42: 921, 2009.

37- VLEEMING A., POOL-GOUDZWAARD A.L., STOECKART R., VAN WINGERDEN J.P. and SNIJDERS C.J.: The Posterior Layer of the Thoracolumbar Fascia, its Function in Load Transfer from Spine to Legs: Spine, 20: 753-8, 1995.

38- BUTLER D.S. and JONES M.A.: Mobilisation of the Nervous System. $1^{\text {st }}$ ed: New York: Churchill Livingstone, 1991.

39- JOHNSON E.K. and CHIARELLO C.M. : The Slump Test: The Effects of Head and Lower Extremity Position on Knee Extension. J. Orthop. Sports Phys. Ther., 26: 310-7, 1997.

40- CHO S.H., KIM S.H. and PARK D.J.: The Comparison of The Immediate Effects of Application of the Suboccipital Muscle Inhibition and Self-Myofascial ReleaseTechniques in The Suboccipital Region on Short Hamstring: J. Phys. Ther. Sci., 27: 195-7, 2015.

41- KAHKESHANI K. and WARD P.J.: Connection Between the Spinal Dura Mater and Suboccipital Musculature: Evidence for The Myodural Bridge and a Route for its Dissection-A Review. Clin. Anat., 25: 415-22, 2012.

42- CRUZ-MONTECINOS: Medicine and Rehabilitation: BMC Sports Science, 8: 18, 2016.

43- CRUZ-MONTECINOS C., GONZÁLEZ A., LÓPEZ D., CERDA M., SANZANA-CUCHE R. and CUESTAVARGAS A.: In vivo relationship between pelvis motion and deep fascia displacement of the medial gastrocnemius: Anatomical and functional implications. J. Anat., 227: 665-72, 2015

44- SCHLEIP R.: Fascial plasticity-a new neurobiological explanation: Part 1. J. Bodyw. Mov. Ther., 7: 11-9, 2003.

45- WILKE J., KRAUSE F., VOGT L. and BANZER W.: What is evidence-based about myofascial chains? A systematic review: Arch. Phys. Med. Rehabil., doi: 10.1016/j.apmr.2015.07.023, 2015.

46- SIVAYOGAM A., JOHNSON G.M. and SKINNER M.A. The effect of cervical protrusion and retraction on postural stability in healthy adults: New Zealand Journal of Physiotherapy, 39 (3): 110-5, 2011.

47- KOGLER, J. LINDFORS, L.M. ÖDKVIST and T. LEDIN: Postural Stability Using Different Neck Positions in Normal Subjects and Patients with Neck Trauma: Acta Oto-Laryngologica, 120: 2, 151-5, doi:10.1080/ $000164800750000801,2000$. 


\section{العلاقة بين الوضعيات المختلفة وكل من مدى الحركة لمفصل الكاحل

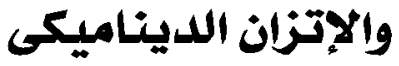

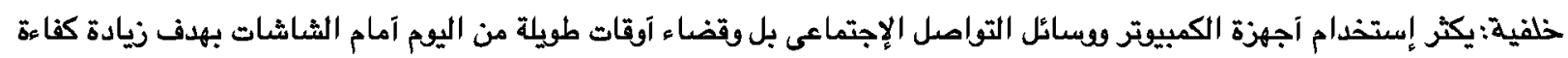

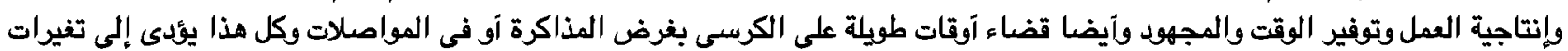

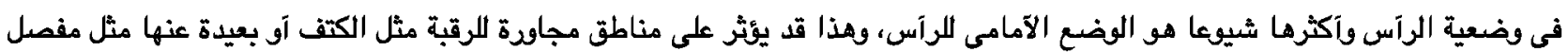

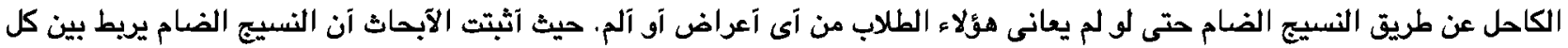

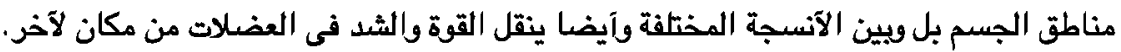
الفرض : يهدف هذا البحث إلى دراسة العلاقة بين وضعية الرآس وكل من مدى الصركة لمفصل الكاحل والإتزان الديناميكى لاى الطلاب الجامعين.

الآشخخاص: وقد آجريت هذه الدراسة على عينة مكونة من خمسة وثلاثون طالبا تم قياس الإتزان الديناميكى لهم عن طريق جهاز البيودكس وآيضا تحليل ثلاثي الآبعاد لوضعية الرآس وقياس مدى الصركة لمفهل الكاحل لريط العلاقات بينهم.

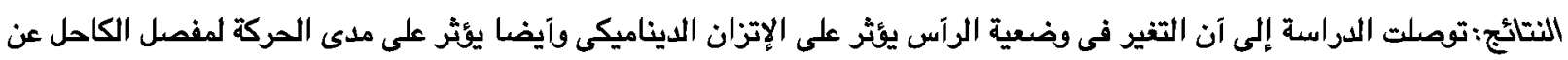

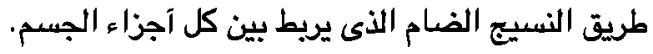

